\title{
DIFFERENT SHADING ENVIRONMENTS IMPACT GROWTH AND YIELD OF THREE MINI-TOMATO CULTIVARS ${ }^{1}$
}

\author{
DIEGO RANGEL DA SILVA GAMA ${ }^{2 *}$, ALESSANDRO CARLOS MESQUITA ${ }^{2}$, JONY EISHI YURI ${ }^{3}$, KALLINE \\ MENDES FERREIRA ${ }^{2}$, VANUZA SOUZA ${ }^{2}$
}

\begin{abstract}
Our study was conducted in the experimental field of the Department of Technology and Social Sciences (DTCS) of the State University of Bahia - UNEB, Juazeiro-BA. The experimental design was comprised of randomized blocks, sub-subdivided in plots, with four replicates comprising the plots of three different shading methods, gray shading screen (GS), red shading screen (RS), and blue shading screen (BS), and the control treatment with no shading. The subplots comprised three mini-tomato cultivars ("Sweet Million", "Red Sugar", and "Shani”), and sub-subplots consisted of seven sampling times. The traits evaluated were: dry matter accumulation in leaves, stems, roots, and fruits, total dry matter, shoot length, root length, total number of fruits, and overall yield. The results of the growth analysis showed that dry matter accumulation in organs of mini tomatoes was similar in all treatments and that the highest total dry matter accumulation occurred under RS. In all treatments, fruit was the preferential drainage; however, the cultivar "Red Sugar" showed higher dry matter accumulation in other plant organs. "Red Sugar" also showed the highest number of fruits per plant; however, when we evaluated total productivity, "Sweet Million" and "Shani" showed similar, higher values than "Red Sugar".
\end{abstract}

Keywords: Solanum lycopersicum. Shading screens. Growth analysis. Red Sugar. Sweet Million. Shani.

\section{IMPACTO DOS DIFERENTES AMBIENTES DE SOMBREAMENTO NO CRESCIMENTO E PRODUTIVIDADE DE TRÊS CULTIVARES DE MINITOMATES}

\begin{abstract}
RESUMO - O trabalho foi conduzido no campo experimental do Departamento de Tecnologia e Ciências Sociais (DTCS), Campus III, da Universidade do Estado da Bahia - UNEB, Juazeiro-BA. O delineamento experimental foi em blocos casualizados, com parcelas subsubdivididas, com quatro repetições, as parcelas compostas de três ambientes sombreados, tela de sombreamento cinza, tela de sombreamento vermelha, e tela de sombreamento azul, mais o tratamento controle, sem sombreamento, as subparcelas formadas por três cultivares de minitomates ("Sweet Million", "Red Sugar", e "Shani") e as sub-subparcelas constituída de sete épocas de amostragens das plantas. As características avaliadas foram: acúmulo de massa seca nas folhas; no caule; nas raízes; nos frutos e total, além do comprimento da parte aérea, comprimento da raiz, o número total de frutos e produtividade. Os resultados de análise de crescimento apresentaram acúmulo de massa seca nos diferentes órgãos das plantas de minitomates, para todos os tipos de ambientes e que o maior acúmulo de massa seca total ocorreu no ambiente com tela vermelha. Em todos os ambientes analisados, o dreno preferencial da planta foi o fruto, contudo, a cultivar Red Sugar acumulou maior massa seca nos outros órgãos da planta em comparação com as demais cultivares. A cultivar Red Sugar obteve a maior quantidade de frutos por planta, entretanto, quando avaliou-se a produtividade total, as cultivares Sweet Million e Shani não diferiram entre si, sendo, superiores aos valores obtidos para a cultivar Red Sugar.
\end{abstract}

Palavras-chave: Solanum lycopersicum. Telas de sombreamento. Análise de crescimento. Red Sugar. Sweet Million. Shani.

\footnotetext{
*Corresponding author

${ }^{1}$ Received for publication in 03/10/2015; accepted in 08/03/2016.

Paper extracted from the master dissertation of the first author.

${ }^{2}$ Department Technology and Sciences Social, Universidade do Estado da Bahia, Petrolina, PE, Brazil; diegorangel85@hotmail.com, alessandro.mesq@yahoo.com.br,kmf.agronomia@gmail.com, van.nuzasouza@hotmail.com.

${ }^{3}$ Empresa Brasileira de Pesquisa Agropecúaria do Semiárido, Petrolina, PE, Brazil; jony.yuri@embrapa.br.
} 


\section{INTRODUCTION}

Tomato (Solanum lycopersicum) is a perennial plant with two basic growth habits, determinate and indeterminate. In indeterminate growth, the main stem grows more than the lateral branches, with apical dominance and growth continuing indefinitely until plant death; in determinate growth, the plant is bushy and medium-sized (FILGUEIRA, 2000).

The tomato is a crop of great economic importance, In Brazil, it covers an area of approximately 60,000 thousand hectares, with an annual production of over 3.76 million tons (IBGE, 2013). Among the northeaster Brazilian states, tomato cultivation is currently performed basically by small rural farmers mainly in the states of Pernambuco, Bahia, and Ceará. Due to its traits, this crop is of great socio-economic importance in these regions, and Bahia and Pernambuco combined are responsible for $45 \%$ of the total northeastern production, i.e., approximately $314,000 \mathrm{t}$ year $^{-1}$ (IBGE, 2013).

Currently, a series of tomato cultivars has been developed, and authors classify cultivars into six different groups or types, according to fruit shape and size: Santa Cruz, Plum, Saladinha, Cherry, Italian, and Agro-industrial (FILGUEIRA, 2000; ALVARENGA, 2004; BOAVENTURA, 2007).

According to Azevedo, Abboud e Carmo (2010), among these different fruit shapes and sizes, cherry tomato has been gaining prominence and increasing its share in the national market. In addition to the types mentioned above, a new type of tomato has been standing out, although its cultivation is still small-sized; it is very promising and has been labeled sweet grape tomato by some people. This group belongs to the segment of mini tomatoes; it is smaller than cherry tomato and its main trait is a higher sugar content, which pleases consumers, mostly children, with the additional advantage of not needing to be sliced when consumed.

However, it is important to note that among fruit crops, the tomato has the highest level of difficulty in production. It is an extremely sensitive culture, mainly in environmental terms, and requires great care throughout its growth cycle. Therefore, one of the ways to overcome environmental adversities is using protected cultivation.

According to Shahak (2008), the use of screens with photosensitive additives enables the selective filtering of solar radiation and makes it possible to turn direct light into diffuse light. This technique increases physiological response, since diffuse lighting allows more intense light absorption by the leaves.

In order to evaluate the behavior of vegetable species in relation to light, some growth variables have been used, among which the most frequently analyzed ones are height, dry matter production, foliar area, and ratios between aerial part and root biomass. Growth analysis allows to evaluate the final growth of the plant as a whole as well as the contribution of the different organs (FAYAD et al., 2001).

Thus, our study aimed to obtain information on growth and development of three mini tomato cultivars using several types of environments.

\section{MATERIAL AND METHODS}

The study was conducted from April to July 2013 in the experimental field of the Department of Technology and Social Sciences (DTCS), Campus III, State University of Bahia - UNEB, Juazeiro-BA $\left(09^{\circ} 24^{\prime} \mathrm{S}, 40^{\circ} 26^{\prime} \mathrm{W}\right)$. The climate is semiarid and, according to the Koeppen classification, defined as "BSwh", with mean annual temperatures of $26^{\circ} \mathrm{C}$ and mean annual precipitation of $514.7 \mathrm{~mm}$ (EMBRAPA, 2013).

The experimental design was comprised of randomized blocks with sub-subdivided plots and four replicates. The plots included four shaded environments with the following shading variations: gray shading screen (GS), red shading screen (RS), and blue shading screen (BS); control treatment consisted of no shading (OS). The sub-plots contained three mini tomato cultivars ("Red Sugar", "Shani", and "Sweet Million"); as sub-subplots, there were seven sampling times: $0,15,30,45,60,75$, and 90 days after transplantation (DAT). Each plot was comprised of 240 plants, divided into sub-plots which were comprised of 80 plants belonging to each cultivar.

For growth analysis, we used the destructive method, in which whole plants were collected throughout their growth cycle up to 90 DAT. One whole plant was removed from each replicate, totaling four plants from each treatment at each sampling time. After harvest, all parts (leaves, stem, roots, and fruits) were weighed separately and placed in a forced ventilation oven at $65^{\circ} \mathrm{C}$ until they reached constant weight. Assessments were performed at the Laboratory of Olericulture of the State University of Bahia.

The seedlings of the three cultivars were placed in 128-cells polystyrene trays filled with the commercial substrate Bioplant ${ }^{\mathbb{R}}$. They remained in the greenhouse for 25 days and were transplanted into the field once they had formed 5 to six leaves.

Soil samples were collected 60 days prior to chemical and physical analyses. Prior to the experiment, ploughing and seedbed preparation were performed, followed by foundation fertilization (COSTA et al., 2008). After preparation and fertilization, a dripping tube line was placed in the central part of each ridge, with $0.40 \mathrm{~m}$ spacing between emitters, and a double-sided plastic film was installed ("mulching"), with the silver side 
facing upwards in each seed bed. Using the sharp ends of an iron tube, we made holes with a spacing of $0.4 \mathrm{~m}$ between plants and $1.4 \mathrm{~m}$ between rows and transplanted one seedling per hole.

In each environment, an automatic meteorological station was installed to monitor solar radiation ( $\left.\mathrm{Rg}, \mathrm{MJ} \mathrm{m}^{-2}\right)$, temperature $\left({ }^{\circ} \mathrm{C}\right)$, and relative air humidity ( $\mathrm{RH}, \%)$ during the tomato productive cycle, which extended to 90 days after transplantation. Tensiometer irrigation management was adopted; two tensiometers were installed in each block of each environment to monitor the need for irrigation.

Top-dressings were performed via fertigation every two days. Sprouting and staking were also performed, since the cultivars used were indeterminate in growth. Plants were sprouted throughout their cycle, and only the main stems remained.

Other farming practices were performed and agricultural defensive substances were applied according to the needs of each culture, considering integrated plague and disease management for each culture.

We evaluated the following traits: dry matter accumulation in leaves, stems, roots, and fruits (DML, DMS, DMR, and DMF, respectively), total dry matter (TDM), obtained by weighing the dry matter in each organ, aerial part length (APL), root length (RL), and the total number of fruits (TNF). Total dry matter in the different plant parts was determined by weighing each selected plant selected after oven-drying at $65^{\circ} \mathrm{C}$ until constant weight.

The results were subjected to variance analysis and the averages were compared using Tukey's test with $5 \%$ of probability for environmental factor and cultivar; regression analysis was used for the sampling season factor, using SISVAR Software (FERREIRA, 2010).

\section{RESULTS AND DISCUSSION}

Highest transmittance was observed in the environment covered with red shading screen $(88.8 \%)$, followed by blue $(74.2 \%)$ and gray shading screen $(52.9 \%)$.

During the experiment, solar radiation in environments in open sun and under red, blue, and gray screen reached a total of $1,342.5,1,192.8$, 996.1, and 699.7 $\mathrm{MJ} \mathrm{m}^{-2}$, respectively. Mean daily values were as follows: (Table 1): open sun $\left(16.6 \mathrm{MJ} \mathrm{m}^{-2}\right)$, red shading screen $\left(14.72 \mathrm{MJ} \mathrm{m}^{-2}\right)$, blue shading screen $\left(12.29 \mathrm{MJ} \mathrm{m}^{-2}\right)$, and gray shading screen $\left(8.63 \mathrm{MJ} \mathrm{m}^{-2}\right)$. Radiation is an important environmental factor for plants due to its direct or indirect impact on growth and development. The adaptations by the plant photosynthetic apparatus in response to environmental lighting conditions reflect growth; such morphophysiological responses of plants do not only depend on the presence, attenuation, or absence of light, but also on variations in light quality (ENGEL; POGGIANI, 1991).

Table 1. Mean values of global solar radiation $(\mathrm{Rg})$, daily solar radiation (daily $\mathrm{Rg}$ ), and relative air humidity (RH) in different types of environments.

\begin{tabular}{cccc}
\hline Environment & Rg $\left(\mathbf{M J ~ m}^{-2}\right)$ & daily $\mathbf{R g}\left(\mathbf{M J ~ m}^{-\mathbf{2}}\right)$ & $\mathbf{R H}(\%)$ \\
\hline Open Sun & 1342.5 & 16.6 & 66.4 \\
Red screen & 1192.8 & 14.72 & 66.0 \\
Blue screen & 996.1 & 12.29 & 65.8 \\
Gray screen & 699.7 & 8.63 & 64.3 \\
\hline
\end{tabular}

In terms of relative air humidity, we observed similar behavior patterns between environments; however, the environment under gray shading screen showed lowest mean humidity values compared to the other environments, which was probably related to the lower solar radiation transmittance in this environment (Table 1).
As shown in Table 2, there were no variations in maximum, medium, and minimum temperatures between environments, with mean air temperature of $25.9,26.2,25.8$, and $25.8^{\circ} \mathrm{C}$, respectively, for open sun environments, environments under red screen, blue screen, and gray screen, showing the same behavior for maximum and minimum temperatures, which were around 35.5 and $16.5^{\circ} \mathrm{C}$.

Table 2. Mean maximum, medium, and minimum air temperatures in different types of environments (OS - open sun, RS red screen, BS - blue screen, and GS - gray screen).

\begin{tabular}{ccccc}
\hline \multirow{2}{*}{ Temperature $\left({ }^{\circ} \mathbf{C}\right)$} & \multicolumn{4}{c}{ Environments } \\
\cline { 2 - 5 } & OS & RS & BS & GS \\
\hline Maximum & 35.5 & 35.8 & 35.4 & 35.4 \\
Medium & 25.9 & 26.2 & 25.8 & 25.8 \\
Minimum & 16.5 & 16.8 & 16.4 & 16.4 \\
\hline
\end{tabular}

Rev. Caatinga, Mossoró, v. 30, n. 2, p. 324 - 334, abr. - jun., 2017 
The results obtained show that among the assessed variables (shading, cultivar, time), there were significant interactions only for stem length and root dry matter. Significant interactions between environment type and sampling time were found for root length, dry leaf matter, dry stem matter, and total plant dry matter, and a significant interaction between cultivar and sampling time were found for the variables root length, dry leaf matter, dry stem matter, dry fruit matter, total plant dry matter, and total number of fruits per plant.
There was a triple significant interaction between environment, cultivar, and sampling time for stem length; we observed this interaction by fixing the factor time while monitoring tomato plant growth. The cultivars inside each type of environment showed a similar behavior up to 30 DAT; after that, distinct behaviors could be observed, stabilizing by 90 DAT. However, we noticed higher stem development in protected environments than in open sun (Table 3 ).

Table 3. Mean values of stem length of three mini-tomato cultivars (RED - Red Sugar, SHANI, and SM - Sweet Million) cultivated in different types of environments.

\begin{tabular}{|c|c|c|c|c|c|c|c|c|c|c|c|c|}
\hline \multicolumn{13}{|c|}{ Stem length $(\mathrm{cm})$} \\
\hline & \multicolumn{3}{|c|}{ Open sun } & \multicolumn{3}{|c|}{ Blue screen } & \multicolumn{3}{|c|}{ Gray screen } & \multicolumn{3}{|c|}{ Red screen } \\
\hline DAT & RED & SHANI & SM & RED & SHANI & SM & RED & SHANI & SM & RED & SHANI & SM \\
\hline 0 & $6.75 \mathrm{Aa}$ & $9.12 \mathrm{Aa}$ & $6.65 \mathrm{Aa}$ & $6.75 \mathrm{Aa}$ & $9.12 \mathrm{Aa}$ & $6.65 \mathrm{Aa}$ & $6.75 \mathrm{Aa}$ & $9.12 \mathrm{Aa}$ & $6.65 \mathrm{Aa}$ & $6.75 \mathrm{Aa}$ & $9.12 \mathrm{Aa}$ & $6.65 \mathrm{Aa}$ \\
\hline 15 & $23.62 \mathrm{Aa}$ & $20.75 \mathrm{Aa}$ & $25.47 \mathrm{Aa}$ & $29.12 \mathrm{Aa}$ & $28.87 \mathrm{Aa}$ & $26.5 \mathrm{Aa}$ & $27.25 \mathrm{Aa}$ & $22.62 \mathrm{Aa}$ & $27.67 \mathrm{Aa}$ & $27.52 \mathrm{Aa}$ & $29.00 \mathrm{Aa}$ & $26.12 \mathrm{Aa}$ \\
\hline 30 & $72.87 \mathrm{Aa}$ & $68.5 \mathrm{Aa}$ & $62.75 \mathrm{Aab}$ & $77.25 \mathrm{Aa}$ & $82.62 \mathrm{Aa}$ & $72.12 \mathrm{Aab}$ & $60.75 \mathrm{Aa}$ & $63.00 \mathrm{Aa}$ & $52.3 \mathrm{Ab}$ & $73.75 \mathrm{Aa}$ & $82.00 \mathrm{Aa}$ & $77.25 \mathrm{Aa}$ \\
\hline 45 & $123.5 \mathrm{ABa}$ & $126.62 \mathrm{Aa}$ & 106.25 Bab & $115.62 \mathrm{Aa}$ & $122.00 \mathrm{Aa}$ & $91.5 \mathrm{Bb}$ & $130.00 \mathrm{Aa}$ & $120.00 \mathrm{Aa}$ & $121.25 \mathrm{Aa}$ & $116.75 \mathrm{Aa}$ & $122.25 \mathrm{Aa}$ & $103.25 \mathrm{Aab}$ \\
\hline 60 & $140.5 \mathrm{Ac}$ & $140.75 \mathrm{Aa}$ & $113.75 \mathrm{Bb}$ & $149.12 \mathrm{Abc}$ & $140.25 \mathrm{Aa}$ & 130.25 Aab & $171.00 \mathrm{Aa}$ & 155.5 Aba & $147.37 \mathrm{Ba}$ & 162.12Aab 1 & $144.75 \mathrm{Aba}$ & $128.5 \mathrm{Bab}$ \\
\hline 75 & $163.75 \mathrm{Ac}$ & $138.25 \mathrm{Bb}$ & $141.00 \mathrm{Bb}$ & $177.5 \mathrm{Abc}$ & 166.00 Aba & $148.75 \mathrm{Bb}$ & $207.25 \mathrm{Aa}$ & $183.75 \mathrm{Ba}$ & $171.75 \mathrm{Ba}$ & 187.25Aab 1 & Aba & $\mathrm{Bab}$ \\
\hline 90 & $156.75 \mathrm{Ab}$ & $160.75 \mathrm{Ab}$ & $148.25 \mathrm{Aa}$ & $168.00 \mathrm{Ab}$ & $158.00 \mathrm{Ab}$ & $156.25 \mathrm{Aa}$ & $214.75 \mathrm{Aa}$ & $201.75 \mathrm{Aa}$ & $150.5 \mathrm{Ba}$ & $194.25 \mathrm{Aa}$ & $166.25 \mathrm{Bb}$ & $158.75 \mathrm{Ba}$ \\
\hline 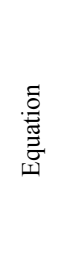 & 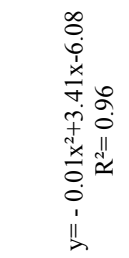 & 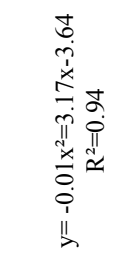 & 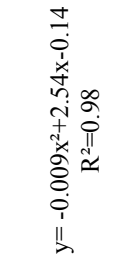 & 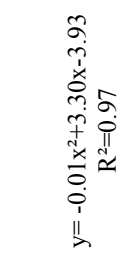 & 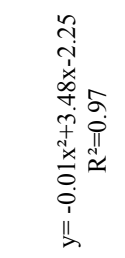 & 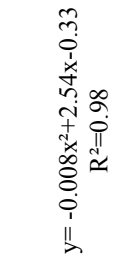 & 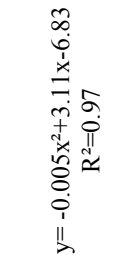 & 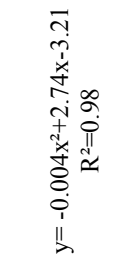 & 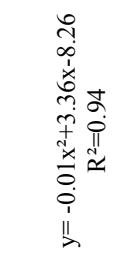 & 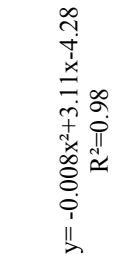 & 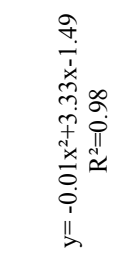 & 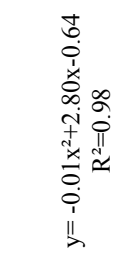 \\
\hline
\end{tabular}

* Means followed by the same lowercase letter in the column and uppercase letter in the row for each factor do not differ statistically using Tukey's test with 5\% probability. Regression analysis equations are in the lower part of the table.

In a similar experiment with tomatoes under different types of shading screens, Rocha (2007) found differences between open sun cultivation and cultivation in protected environments; namely, in protected environments, stem length significantly increased up to 60 DAT compared to environments at open sun. In our study, the environment with gray shading screen received lowest solar radiation (699.7 $\mathrm{MJ} \mathrm{m}^{2}$ ), but tomato plants showed highest stem length values, suggesting that growth was inversely related to radiation. Similar results were obtained in a study conducted by Rocha (2007), who observed highest stem length values and lowest solar radiation under GS.

In all tested environments apart from open sun, the cultivar "Red Sugar" obtained the highest stem length values. The cultivar "Shani" showed a similar behavior in all environments, while "Sweet Million" showed lowest stem length values in all tested environments.

Comparing cultivars in each environment during the sampling seasons, "Red Sugar" showed a similar development up to 45 DAT in all four types of environments, and after this period, stem growth differed between environments; this cultivar obtained the highest stem length values under GS and RS, with 214.75 and $194.25 \mathrm{~cm}$, respectively. On the other hand, "Shani" had a similar stem growth up to 60 DAT in all environments; after that, it showed variation in stem length between environments; this cultivar obtained highest stem growth under GS, with $201.75 \mathrm{~cm}$. The cultivar "Sweet Million" showed a similar behavior for stem length up to $15 \mathrm{DAT}$. After that, there was a difference in stem growth between environments, with highest stem growth $(158.75 \mathrm{~cm})$ under RS.

Fayad et al. (2001), in an experiment with the field-cultivated, indeterminately growing tomato cultivar "Santa Clara", observed that stem length increased throughout the whole duration of the experiment, reaching $146 \mathrm{~cm}$. Cultivars showed quadratic significance in the environments throughout the days assessed, with a similar behavior in all cultivars. 
There was a triple significant interaction between environment, cultivar, and sampling time for dry matter accumulation in roots. Cultivars in environments under RS showed a similar behavior up to 15 DAT; under OS and BS, behavior was similar up to 45 DAT; under GS, up to 60 DAT.
Afterwards, the cultivars in each environment started to show distinct behaviors, stabilizing by 75 DAT (Table 4). "Red Sugar" obtained the highest dry matter accumulation in roots at OS, GS, and RS, and cultivar Shani obtained the highest values under BS.

Table 4. Mean values of dry matter accumulation in root of three mini-tomato cultivars (RED - Red Sugar, SHANI, and SM - Sweet Million) cultivated in different types of environments.

\begin{tabular}{|c|c|c|c|c|c|c|c|c|c|c|c|c|}
\hline \multicolumn{13}{|c|}{ Dry matter accumulation in root $(\mathrm{g})$} \\
\hline & \multicolumn{3}{|c|}{ Open sun } & \multicolumn{3}{|c|}{ Blue screen } & \multicolumn{3}{|c|}{ Gray screen } & \multicolumn{3}{|c|}{ Red screen } \\
\hline DAT & RED & SHANI & SM & RED & SHANI & SM & RED & SHANI & SM & RED & SHANI & SM \\
\hline 0 & $0.02 \mathrm{Aa}$ & $0.02 \mathrm{Aa}$ & $0.01 \mathrm{Aa}$ & $0.02 \mathrm{Aa}$ & $0.02 \mathrm{Aa}$ & $0.01 \mathrm{Aa}$ & $0.02 \mathrm{Aa}$ & $0.02 \mathrm{Aa}$ & $0.01 \mathrm{Aa}$ & $0.02 \mathrm{Aa}$ & $0.02 \mathrm{Aa}$ & $0.01 \mathrm{Aa}$ \\
\hline 15 & $0.22 \mathrm{Aa}$ & $0.22 \mathrm{Aa}$ & $0.12 \mathrm{Aa}$ & $0.29 \mathrm{Aa}$ & $0.16 \mathrm{Aa}$ & $0.16 \mathrm{Aa}$ & $0.18 \mathrm{Aa}$ & $0.13 \mathrm{Aa}$ & $0.13 \mathrm{Aa}$ & $0.12 \mathrm{Aa}$ & $0.26 \mathrm{Aa}$ & $0.1 \mathrm{Aa}$ \\
\hline 30 & $2.0 \mathrm{Aa}$ & $4.0 \mathrm{Aa}$ & $1.75 \mathrm{Aa}$ & $2.0 \mathrm{Aa}$ & $3.5 \mathrm{Aa}$ & $2.75 \mathrm{Aa}$ & $2.0 \mathrm{Aa}$ & $3.0 \mathrm{Aa}$ & $1.25 \mathrm{Aa}$ & $5.25 \mathrm{Aa}$ & $6.0 \mathrm{Aa}$ & $2.0 \mathrm{Ba}$ \\
\hline 45 & $8.5 \mathrm{Aa}$ & $8.5 \mathrm{Aab}$ & $6.0 \mathrm{Aa}$ & $3.5 \mathrm{Ab}$ & $5.5 \mathrm{Ab}$ & $3.5 \mathrm{Aa}$ & $4.5 \mathrm{Ab}$ & $5.5 \mathrm{Ab}$ & $3.5 \mathrm{Aa}$ & $6.5 \mathrm{ABab}$ & $9.0 \mathrm{Aa}$ & $3.5 \mathrm{Ba}$ \\
\hline 60 & $10.25 \mathrm{Aa}$ & $9.25 \mathrm{Aa}$ & $5.5 \mathrm{Ba}$ & $7.75 \mathrm{ABa}$ & 8.75 Aa & $4.75 \mathrm{Ba}$ & $8.0 \mathrm{Aa}$ & $8.5 \mathrm{Aa}$ & $6.5 \mathrm{Aa}$ & $9.0 \mathrm{Aa}$ & $8.5 \mathrm{Aba}$ & $5.75 \mathrm{Ba}$ \\
\hline 75 & $10.85 \mathrm{Aa}$ & $8.02 \mathrm{ABab}$ & $4.97 \mathrm{Ba}$ & $7.4 \mathrm{Ab}$ & 10.1 Aa & $4.17 \mathrm{Ba}$ & 9.7 Aab & $5.0 \mathrm{Bb}$ & $5.12 \mathrm{Ba}$ & $10.85 \mathrm{Aa}$ & $6.2 \mathrm{Bb}$ & $6.35 \mathrm{Ba}$ \\
\hline 90 & $14.12 \mathrm{Aa}$ & $8.45 \mathrm{Bb}$ & $4.95 \mathrm{Ca}$ & $7.2 \mathrm{Bb}$ & $14.47 \mathrm{Aa}$ & $4.42 \mathrm{Ba}$ & $8.7 \mathrm{Ab}$ & $7.3 \mathrm{Ab}$ & $3.5 \mathrm{Ba}$ & $9.62 \mathrm{Ab}$ & $3.27 \mathrm{Bc}$ & $6.55 \mathrm{Aa}$ \\
\hline 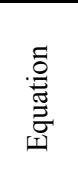 & 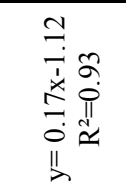 & 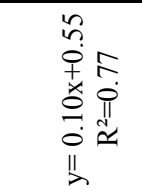 & 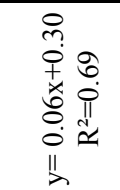 & 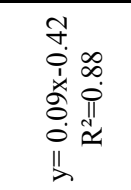 & 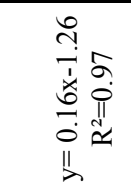 & 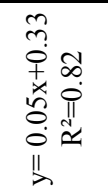 & 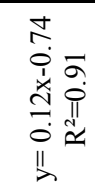 & 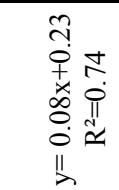 & 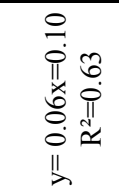 & 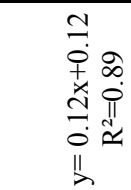 & 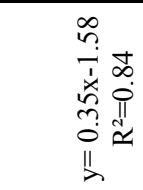 & 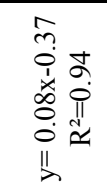 \\
\hline
\end{tabular}

*Means followed by the same lowercase letter in the column and uppercase letter in the row for each factor do not differ statistically using Tukey's test with 5\% probability. Regression analysis equations are in the lower part of the table.

Considering all sampling times of each cultivar in all environments, "Red Sugar" had highest dry matter accumulation in roots in OS. The growth of "Shani" positively stood out under OS and BS, and "Sweet Million" showed similar root dry matter values at all sampling times and in all environments.

There was a significant interaction between root length (Figures $1 \mathrm{a}$ and $1 \mathrm{~b}$ ) and different types of environments and sampling times, with a quadratic response to all types of environments. We also observed rapid growth up to 60 DAT, with subsequent growth stabilization from 60 to 90 DAT, coinciding with the reproductive season. Among the environments (Figure 1a), plants under GS obtained the highest root length values, while plants in OS obtained the lowest length values.

There was also a significant interaction when cultivars were compared to sampling times, showing a similar and quadratic behavior, with rapid growth up to 60 DAT (Figure 1b). After 60 DAT, "Red Sugar" obtained the highest values, followed by
"Sweet Million", with continued, albeit decreased, growth after 60 DAT. In contrast, growth of the cultivar "Shani" was stable after 60 DAT.

There was a significant interaction between the different types of environments and sampling times; total leaf dry matter (Figure 2a) showed a quadratic response in all cultivation environments, with a rapid growth up to 60 DAT and a trend towards stabilization after 70 DAT, due to senescence and foliar abscission.

Fayad et al. (2001), evaluating the indeterminately growing hybrid EF-50 in a protected experiment, observed a similar behavior in terms of dry matter values in leaves, which was rapid up to 60 DAT and stabilized from 75 DAT onwards.

Lopes et al. (2011), conducting an experiment with tomatoes in different types of soil covers, observed a similar behavior for dry matter accumulation in leaves, with a slow growth up to approximately 28 DAT, increasing from then onwards, and a trend towards after 70 DAT. 

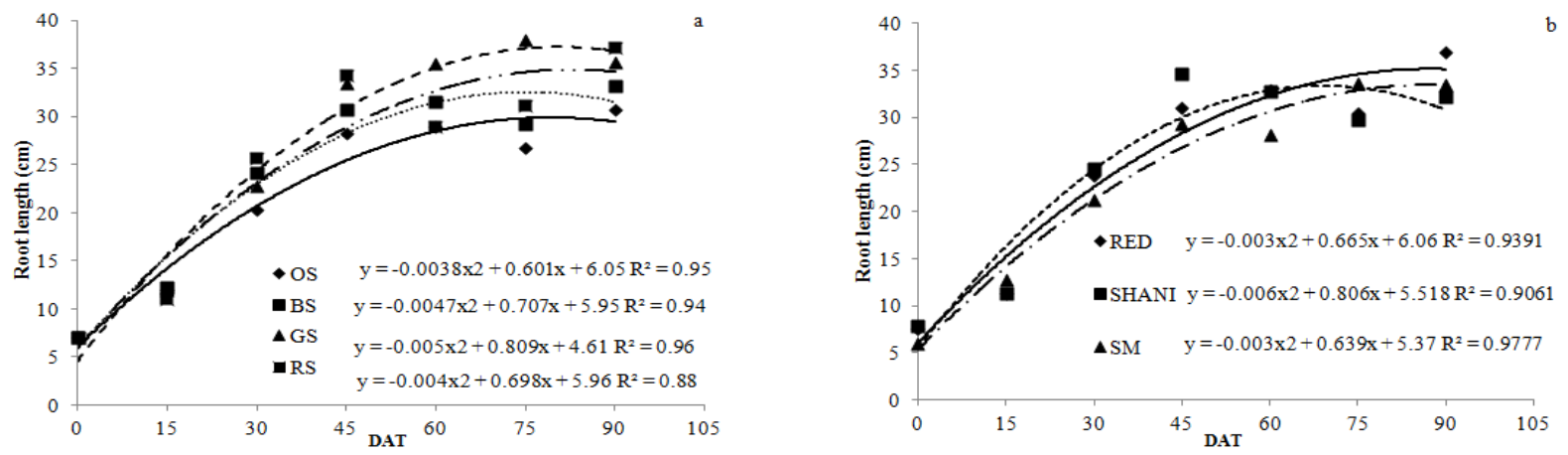

Figure 1a and 1b. Root length of three mini-tomato cultivars (RED - Red Sugar, SHANI, and SM- Sweet Million) in different environments (OS- open sun, BS- blue screen, GS- gray screen, and RS- red screen).
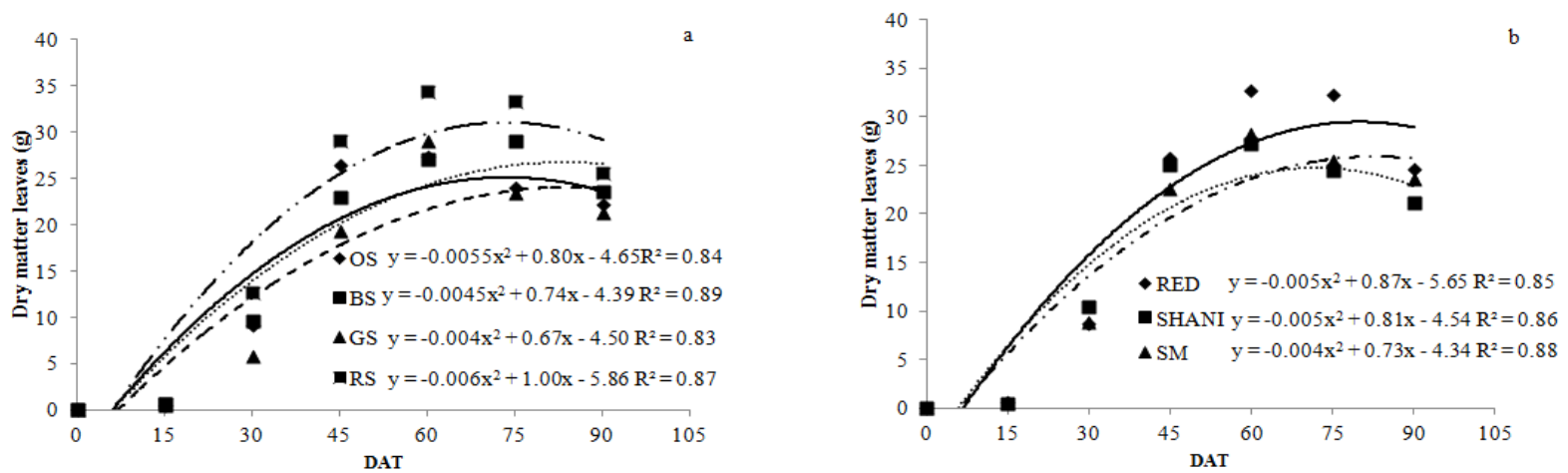

Figure 2a and 2b. Dry matter accumulation in leaves of three mini-tomato cultivars (RED - Red Sugar, SHANI, and SM - Sweet Million) in different environments (OS- open sun, BS- blue screen, GS- gray screen, and RS- red screen).

Figure $2 \mathrm{a}$ shows that in the environment under RS, dry matter values were higher compared to the other environments, with maximum values by 60 DAT, with 34.33 g plant $^{-1}$, whereas under OS, we observed lowest values, reaching their maximum by 60 DAT, with 27.33 g plant $^{-1}$. It is worth noting that the environment under RS received solar radiation similar to that under OS. Therefore, shading screens provided a better quality and distribution of solar radiation in the protected environment, although they caused little reduction in radiant light intensity, resulting in a higher dry matter accumulation in leaves. Rocha (2007), working with tomatoes under several different types of shading screens, observed that, regardless of the cultivation environment, shaded environments had the highest photoassimilate accumulation from 30 to 60 DAT, which also occurred in our experiment. This verifies the higher photosynthetic efficiency, represented by the higher photoassimilate production and accumulation in protected environments than in open sun environments.

There was also a significant interaction between cultivars and sampling times (Figure $2 b$ ) for "Red Sugar", which showed a quadratic behavior and a higher dry matter accumulation in leaves than the other cultivars.
Rapid dry matter accumulation in leaves was observed in the three tested cultivars up to 60 DAT, stabilizing soon after that. Maximum dry matter accumulation in leaves of "Red Sugar", "Sweet Million", and "Shani" was reached at 60 DAT, with mean values of $32.75,28.25$, and $27.25 \mathrm{~g}_{\text {plant }}{ }^{-1}$, respectively.

Regarding dry stem matter, there was a significant interaction between treatments and sampling times. Dry matter accumulation in stems showed a rapid growth from 30 to 75 DAT in all treatments (Figure 3a). From then onwards, there was a slight reduction in growth and a trend towards stabilization.

The same behavior described above was reported by Lopes et al. (2011), who observed that tomatoes grown in open sun and different types of soil cover showed slow growth up to $28 \mathrm{DAT}$, with a higher growth from then onwards and a trend towards stabilization at 70 DAT in all soil covers. Fayad et al. (2001), in experiments with the protected-grown tomato hybrid EF-50 and the field-grown cultivar Santa Clara, also observed similar dry matter accumulation in the stem, which increased from 30 to 75 DAT and tended to stabilize after that. 

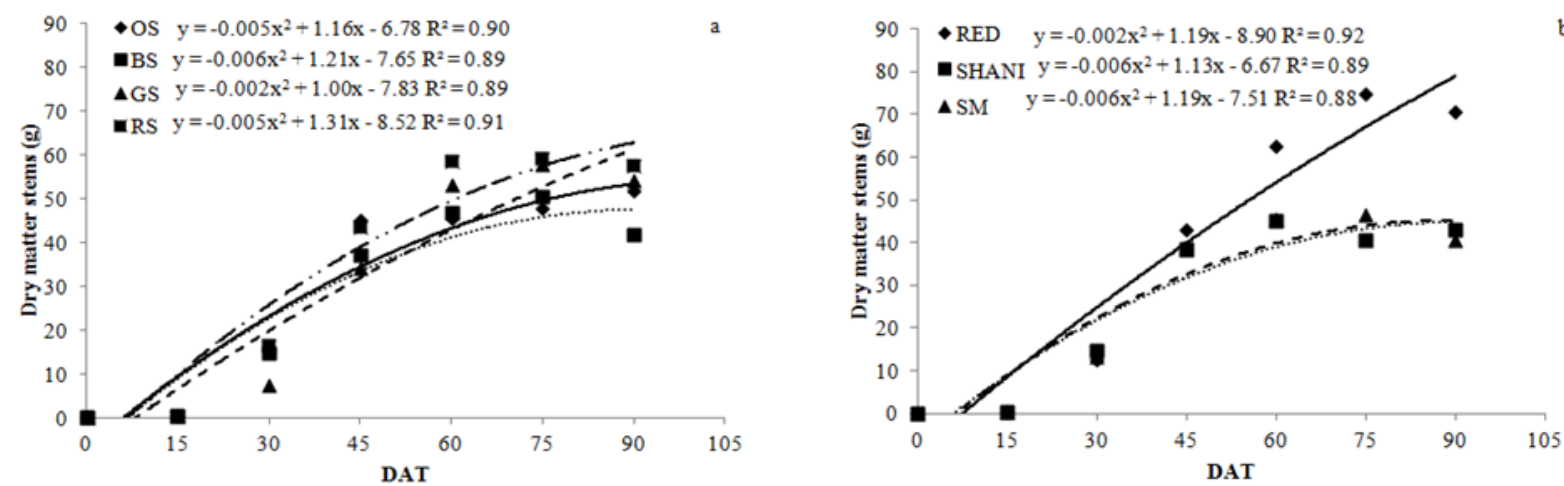

Figures 3a and 3b. Dry matter accumulation in stems of three mini-tomato cultivars (RED - Red Sugar, SHANI, and SM - Sweet Million) in different environments (OS- open sun, BS- blue screen, GS- gray screen, and RS- red screen).

Figure 3a shows that the highest values of dry matter accumulation in the stem were observed under RS, GS, OS, and BS, respectively. The interaction between cultivars and sampling times was also significant (Figure 3b); "Red Sugar" obtained the highest dry matter accumulation in the stem, showing a rapid and continuous accumulation throughout the experiment. However, this was not observed for "Sweet Million" and "Shani", with rapid accumulation up to 60 DAT and stabilization after 75 DAT.
Dry fruit matter and number of fruits per plant did not show significant interactions between treatments and sampling times. However, when only treatments were considered, there was a significant difference in total number of fruits per plant, indicating that under RS, highest numbers of fruit per plant were obtained, with 122.33 fruits plant ${ }^{-1}$, whereas under GS, lowest numbers were obtained, 98.14 fruits plant $^{-1}$ (Figure 4). Lower solar radiation under GS might be a reason for the lower number of fruits per plant, solar radiation impacts fruit yield and quality.

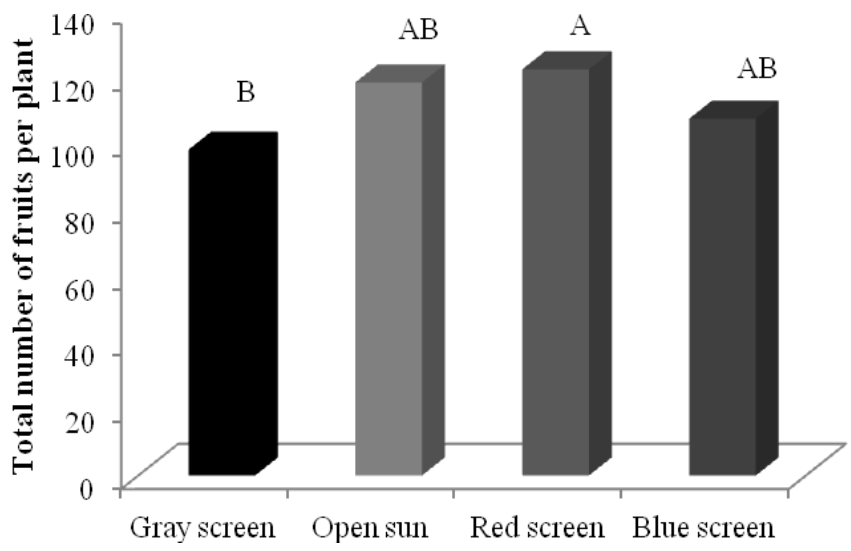

Figure 4. Total number of fruits per plant in different environments.

With increasing plant age, the rise in number and growth of fruits yielded increased dry matter accumulation. However, there was no difference in dry matter accumulation between treatments. Once the plants entered the reproductive phase and set fruits, higher amounts of photoassimilates were directed towards the fruits, resulting in a rapid growth of dry fruit matter from 45 to 90 DAT, with maximum dry matter accumulation at the end of the experiment (90 DAT) (Figure 5a).

Lopes et al. (2011), testing different types of soil covers for tomato production, observed a similar behavior, with rapid growth in dry fruit matter from 42 to 84 and decreased growth from 84 to 98 DAT, when maximum dry matter accumulation in fruits was observed. Similarly, Fayad et al. (2001), evaluating the cultivar "Santa Clara" in the field, also obtained a similar behavior regarding dry matter accumulation in fruits, with increased accumulation from 45 DAT up to the end of the experiment.

Interaction between cultivars and sampling times (Figures 5a and 5b) was significant both for dry matter accumulation in fruits and total number of fruits per plant, which behaved in a linear and increasing manner from 30 DAT onwards, when the first blossoms were fertilized; after 45 DAT, fruit accumulation and production were more intense and rapid. 

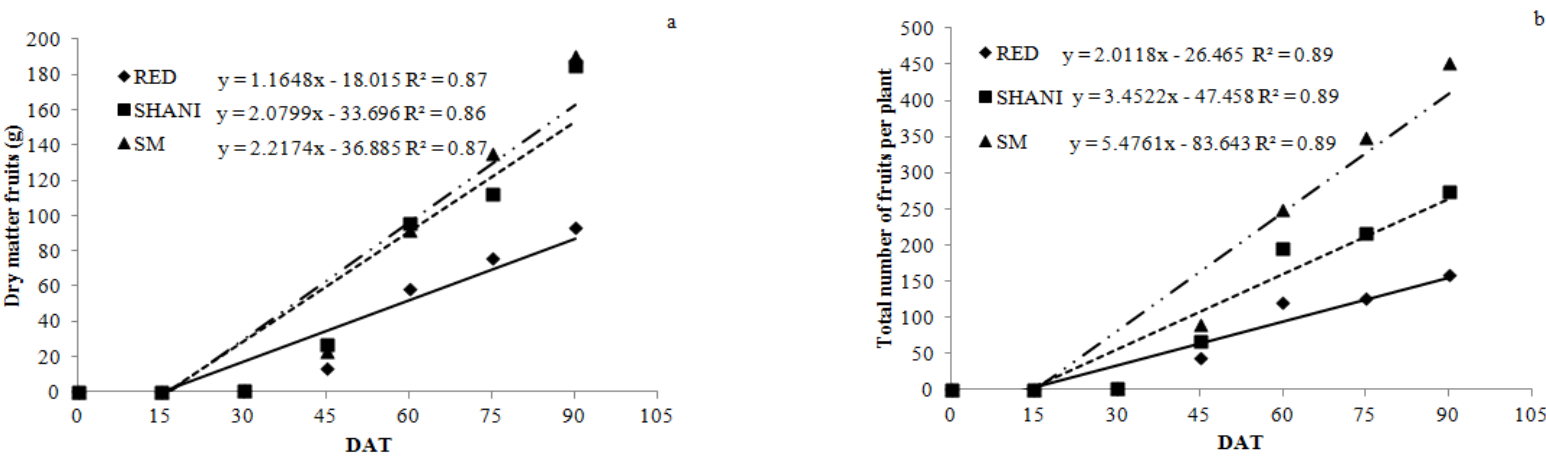

Figure 5a and 5b. Dry matter accumulation in fruits and total number of fruits per plant of three mini-tomato cultivars in different environments (OS- open sun, BS- blue screen, GS- gray screen, and RS- red screen).

Fontes et al. (1997), in an experiment with different tomato cultivars in a plastic-covered greenhouse, observed that the number of fruits per plant was influenced by genotypes and types of environment, with a significant advantage in protected environments compared to open sun cultivation. This was also observed in our experiment.

The cultivars with the highest dry matter accumulation in fruits were "Sweet Million", with a mean value of $190.14 \mathrm{~g}$ plant $^{-1}$, followed by "Shani", with $184.96 \mathrm{~g}$ plant $^{-1}$ and "Red Sugar", with 93.08 g plant $^{-1}$ (Figure 5a). The differences observed in dry fruit matter of the evaluated cultivars might be attributed to genotypic differences, since there was no interaction between treatments and sampling time and no significant difference between treatments.

Fruit development (Figure 5b) started at 30 DAT, and soon after 45 DAT, all three cultivars showed similar, rapid fruit growth. At the end of the experiment (90 DAT), "Sweet Million" had produced an average of 451.68 fruits plant ${ }^{-1}$, followed by "Red Sugar" with 157.68 fruits plant" and "Shani" with 274.43 fruits plant ${ }^{-1}$ (Figure 5b).

Abrahão, Bôas and Bull (2014), evaluating yields of two mini-tomato cultivars during two seasons, observed that "Sweet Million" produced the higher number of fruits (227 and 236 fruits plant ${ }^{-1}$ in the 1 st and 2 nd seasons, respectively), which was lower than that obtained in our study. Gusmão, Gusmão and Araújo (2006), working with protected-grown cherry tomato cultivars in different substrates, obtained a mean value of 283.41 fruits plant $^{-1}$ with cultivar "Sweet Million". In another study by Holcman, Sentelhas and Mello (2015), also on protected-grown cherry tomatoes with different plastic covers, the authors obtained a mean value of 405.1 fruits plant ${ }^{-1}$ for the same cultivar.

Total dry matter accumulation was influenced by treatments and sampling times, with a linear and slow behavior up to $30 \mathrm{DAT}$, increasing from this moment onwards, when the plant entered the blooming and reproductive stage, and intensifying between 45 and 90 DAT, which corresponds to the phase with higher growth and fruit development
(Figure 6a). Fayad et al. (2001), in an experiment with the field-grown tomato cultivar Santa Clara, also observed a similar behavior of total dry matter accumulation, which was rapid from 45 to 90 DAT, corresponding to the fruiting period. Lopes et al. (2011), testing different types of soil covers in tomato production, observed a similar behavior, with slow growth in the first 28 DAT and subsequent increase, when the plant entered the reproductive stage, intensified between 42 and 84 DAT, with maximum accumulation at 98 DAT. In the all treatments, plants reached maximum accumulation at 90 DAT, with highest values under RS (248.6 g plant $^{-1}$ ) (Figure 6a).

There was a significant interaction between cultivars and sampling times, with linear and slow growth up to 30 DAT and subsequent acceleration (Figure 6b). "Sweet Million" and "Shani" reached similar, higher values for total dry matter accumulation. Although "Red Sugar" had obtained higher dry matter accumulation in the stem (Figure $3 b$ ), leaves (Figure 2b), and roots (Table 4) by the end of the experiment, total dry matter accumulation in this cultivar was lowest, which might be attributed to the relatively low amount of fruits.

Dry matter accumulation in different organs of mini tomatoes followed the same pattern in all treatments. However, the cultivars "Shani" and "Sweet Million" showed higher total dry matter values at the end of the experiment, with around $60 \%$ of assimilates distributed to fruits, $25 \%$ to stems, $12 \%$ to leaves, and $3 \%$ to roots (Figure 7 ).

In contrast, "Red Sugar" showed lower dry matter accumulation in fruits, distributing approximately $36 \%$ of assimilates to fruits, $40 \%$ to the stem, $18 \%$ to the leaves, and $6 \%$ to the roots.

In a similar study, Heuvelink (1995) observed that, of the total dry matter produced by the protected-grown cultivar "Counter", cultivated during summer, $60 \%$ was allocated to fruits, $28 \%$ to leaves, and $12 \%$ to stems; the percentage of distribution to leaf and stem was inversely related to the data obtained in our study, which was most likely due to the fact that the cultivar "Counter" is determinate in growth. 

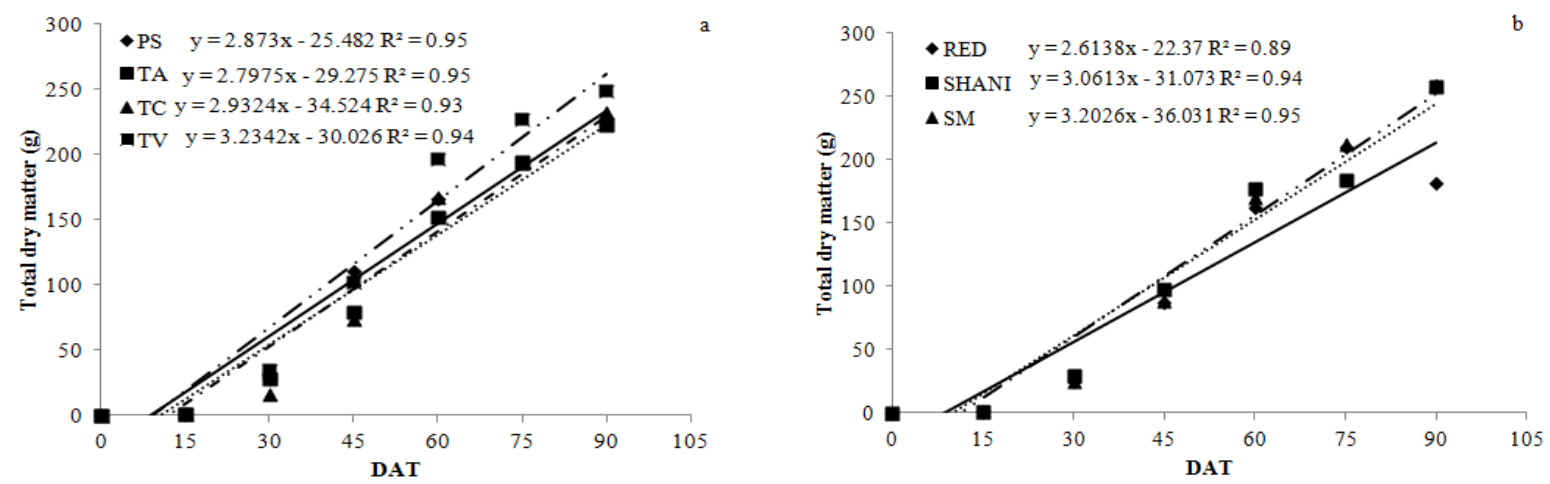

Figure 6a and $6 \mathbf{b}$. Total dry matter accumulation of three mini-tomato cultivars in different environments (OS- open sun, BS- blue screen, GS- gray screen, and RS- red screen).

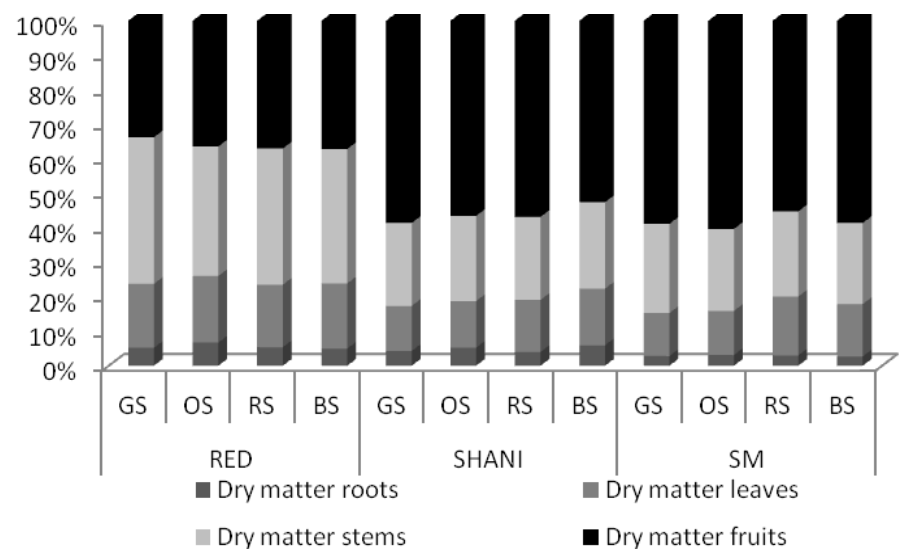

Figure 7. Assimilate distribution to different plant organs of three mini-tomato cultivars in different environments (OSopen sun, BS-blue screen, GS- gray screen, and RS- red screen).

According to Fayad et al. (2001), the production of above-ground dry matter in the field-cultivated, indeterminately growing tomato cultivar "Santa Clara" was highest at 120 days after seedling transplantation, reaching $406.3 \mathrm{~g} \mathrm{plant}^{-1}$; fruit was the main plant drainage, accumulating up to $51 \%$ of the total dry matter of the aerial part produced by the plant, followed by $33 \%$ for leaves and $14 \%$ for the stem. The same authors also observed that highest dry matter amounts were found in fruits of the cultivar "EF-50"; by the end of the growth cycle, $25 \%$ of the total yielded dry matter was found in the leaves, $5 \%$ in the stem, $2 \%$ in the flower trusses, and $68 \%$ in the fruits.

There was no significant interaction between treatments and cultivars regarding yield; however, there was a significant difference when the cultivar factor was evaluated separately. "Shani" and "Sweet Million" showed the highest yields, corroborating the values of dry fruit matter (Figure 5a) and number of fruits per plant (Figure 5b), which were higher than the values for "Red Sugar". Abrahão, Bôas and Bull (2014), testing two mini-tomato cultivars, observed that "Sweet Million" obtained the highest yield, with an average of $29.9 \mathrm{t} \mathrm{ha}^{-1}$, which is lower than the value found in our study. As seen in the assimilate partitioning in Figure 7, dry matter accumulation in fruits of the cultivar "Red Sugar" was lower, resulting in a lower number of fruits and lower yield values (Table 5).

Table 5. Mean yield values for three mini-tomato cultivars.

\begin{tabular}{cc}
\hline Cultivar & Yield (t ha-1) \\
\hline Red Sugar & $12.62 \mathrm{~b}$ \\
Shani & $31.20 \mathrm{a}$ \\
Sweet Million & $32.88 \mathrm{a}$ \\
\hline \multirow{2}{*}{ *Means followed by the same letter do not } \\
differ statistically through the Tukey's test \\
with 5\% significance.
\end{tabular}

Rev. Caatinga, Mossoró, v. 30, n. 2, p. 324 - 334, abr. - jun., 2017 
Different amounts of solar radiation on mini-tomatoes cultivated in the different environments might have caused changes in the physiological behavior of the plants, since tomatoes cultivated under RS obtained highest dry matter values in leaves, stem, fruits, and highest numbers of fruits per plant; however, there was no significant difference in yield between the treatments. Therefore, the amount of solar radiation might influence differences in the production of aerial part biomass, thereby impacting yields.

\section{CONCLUSIONS}

Our results show that under RS, highest total dry matter accumulation in all analyzed cultivars can be achieved. As expected, most of the dry matter was accumulated in the fruits, regardless of the treatment; however, the cultivar "Red Sugar" differently distributed dry mass to its other organs (stem, leaves, and roots) compared to other tested cultivars. "Red Sugar" also had the lowest number of fruits per plant, while "Sweet Million" and "Shani" showed similar productivity levels, which were higher than that for the cultivar "Red Sugar".

\section{REFERENCES}

ABRAHÃO, C.; BÔAS, R. L. V.; BULL, L. T. Relação $\mathrm{K}: \mathrm{Ca}: \mathrm{Mg}$ na solução nutritiva para a produção de minitomate cultivado em substrato. Irriga, Botucatu, v. 19, n. 2, p. 214-224, 2014.

ALVARENGA, M. A. R. de. Tomate: produção em campo, em casa de vegetação e em hidroponia. 1 . ed. Lavras, MG: EDITORA UFLA, 2004. p. 15-23.

AZEVEDO, V. F.; ABBOUD, A. C. S.; CARMO, M. G. F. Row spacing and pruning regimes on organically grown cherry tomato. Horticultura Brasileira, Brasília, v. 28, n. 4, p. 389-394. 2010.

BOAVENTURA. R. C. Viabilidade técnica do cultivo de tomate em estufa no distrito federal. 1. ed. Planaltina, DF: UPIS - Faculdades integradas, $2007.63 \mathrm{p}$.

COSTA, N. D. et al. Tomate rasteiro irrigado. Recomendações de adubação para o estado de Pernambuco. 2. ed. Recife, PE: IPA - Instituto Agronômico de Pernambuco, 2008. 195 p.

EMPRESA BRASILEIRA DE PESQUISA AGROPECUÁRIA - EMBRAPA. Médias Anuais da Estação Agrometeorológica de Bebedouro. Disponível em: http://www.cpatsa.embrapa.br:8080/ servicos/dadosmet/ceb-anual.html. Acesso em: 17 jan. 2013.

ENGEL, V. L.; POGGIANI, F. Estudo da concentração de clorofila nas folhas e seu espectro de absorção de luz em função do sombreamento em mudas de quatro espécies florestais nativas. Revista Brasileira de Fisiologia Vegetal, Londrina, v. 3, n. 1, p. 39-45, 1991.

FAYAD, J. A. et al. Crescimento e produção do tomateiro cultivado sob condições de campo e de ambiente protegido. Horticultura Brasileira, Brasília, v. 19, n. 3, p. 232-237. 2001.

FERREIRA, D. F. SISVAR Versão 5.3. Lavras: Departamento de Ciências Exatas, UFLA. 2010.

FILGUEIRA, F. A. R. Novo manual de olericultura: agrotecnologia moderna na produção e comercialização de hortaliças. 2. ed. rev. ampl.,Viçosa, MG: EDITORA UFV, 2000. 402 p.

FONTES, P. C. R. et al. Produção de Cultivares de Tomate em Estufa Coberta com Plástico. Revista Ceres, Viçosa, v. 44, n. 252, p. 152-160. 1997.

GUSMÃO M. T. A.; GUSMÃO S. A. L.; ARAÚJO J. A. C. Produtividade de tomate tipo cereja cultivado em ambiente protegido e em diferentes substratos. Horticultura Brasileira, Brasília, v. 24, n. 4, p. 431-436. 2006.

HEUVELINK, E. Growth, development and yield of a tomato crop: periodic destructive measurements in greenhouse. Scientia Horticulturae, Netherlands, v. 61, n. 1, p. 77-99, 1995.

HOLCMAN, E.; SENTELHAS, P. C.; MELLO, S. C. Alterações microclimáticas provocadas por diferentes coberturas plásticas em ambiente protegido cultivado com tomate tipo cereja no sudeste do Brasil. Revista Brasileira de Meteorologia, São Paulo, v. 30, n. 2, p. 125-133, 2015 .

INSTITUTO BRASILEIRO DE GEOGRAFIA E ESTATÍSTICA - IBGE. Levantamento sistemático da produção agrícola. Rio de Janeiro, RJ, v. 26, n. 9, p. 1-84., 2013.

LOPES, W. A. R. et al. Análise do crescimento de tomate 'SM-16' cultivado sob diferentes coberturas de solo. Horticultura Brasileira, Brasília, v. 29, n. 4, p. 554-561. 2011

ROCHA, R. C. Uso de diferentes telas de sombreamento no cultivo protegido de tomateiro. 2007. 90 f. Tese (Doutorado em Agronomia) Universidade Estadual Paulista, Faculdade de 
Ciências Agronômicas, Botucatu, 2007.

SHAHAK, Y. Photo-selective netting for improved performance of horticultural crops. A review of ornamental and vegetable studies carried out in Israel. Acta Horticulture, Leuven, v. 797, n. 770, p. 75-80. 2008. 